\title{
An economic impact analysis of market and policy changes in a New Brunswick Fundy Model Forest community
}

\author{
by Van A. Lantz ${ }^{1}$ and Yigezu A. Yigezu ${ }^{2}$
}

\begin{abstract}
A two-sector computable general equilibrium model is calibrated to the New Brunswick community of Petitcodiac using translog cost function regression analysis, and a questionnaire. Simulations are conducted for marginal reductions in both the price of lumber and the timber supply. We observe that both reductions have negative impacts on output and most production factors in the forest sector. Other production sectors tend to expand as production factors flow to where they receive their highest return. Results of this study indicate that the New Brunswick community is more (less) significantly impacted from timber supply (forest price) changes than a comparative study reports for a region in Alberta.
\end{abstract}

Key words: CGE model, translog cost function, timber supply, lumber prices, regional economics, community impact

Un modèle informatique d'équilibre général de deux secteurs est calibré pour la communauté de Petitcodiac au moyen d'une analyse de fonction de régression « translog » et d'un questionnaire. Des simulations ont été réalisées pour des réductions marginales tant du prix du bois de sciage que pour l'approvisionnement en bois. Nous observons que les deux réductions génèrent des impacts négatifs sur les extrants et sur la plupart des facteurs de production de l'industrie forestière. Les autres secteurs de production ont tendance à croître alors que les facteurs de production se déplacent là où ils obtiennent le plus fort rendement. Les résultats de cette étude indiquent que la communauté néo-brunswickoise subit un impact plus (moins) significatif face aux fluctuations (des prix en forêt) des approvisionnements en bois que dans le cas d'une région en Alberta selon des rapports d'étude comparables.

Mots-clés: Modèle CGE, fonction des coûts “translog”, approvisionnement en bois, prix du bois de sciage, économie régionale, impact régional

\section{Introduction}

The forest industry plays an important role in the welfare of local communities in the Fundy Model Forest (FMF) region of New Brunswick. In 2000, this industry employed over 4615 people and produced over $\$ 619$ million worth of timber. ${ }^{3}$ These figures account for an important share of this region's contribution to provincial employment and gross domestic product. With approximately 25 communities in this region designated as moderately or highly forest-dependant (MacGregor 2001), it is clear that changes in the forest industry will have significant impacts on FMF residents.

The fate of the Fundy forest industry has become increasingly uncertain in recent years. This uncertainty, which exists in many Canadian forest regions, stems primarily from two concerns. First, world forest product prices are projected to decrease in the long run. ${ }^{4}$

This projection is largely due to the expected increase in global supply of forest products from plantations in Latin America and South East Asia. These southern suppliers are increasingly establishing a comparative advantage over producers in northern regions such as New Brunswick. The comparative advantage is being created from regional differences in timber growth rates, rotation age, labour costs, and environmental regulations (Alavalapati et al. 1999b).

\footnotetext{
${ }^{1}$ Assistant Professor, Faculty of Forestry and Environmental Management and Department of Economics, University of New Brunswick, Fredericton, New Brunswick E3B 6C2. E-mail: vlantz@unb.ca (Author to whom correspondence should be sent.)

${ }^{2}$ Graduate Student, Department of Economics, University of New Brunswick. E-mail: yatnafe@ hotmail.com

${ }^{3}$ The value of timber is computed using MacGregor and MacFarlane's (2000) harvest estimates and applying an average price of $\$ 543.75 / \mathrm{m}^{3}$, as calculated from NSFPMB (2002).

${ }^{4}$ Converting Sohngen et al.'s (1997) world forest product price projections to real values (accounting for inflation) reveals a long-run declining trend for most demand scenarios.
}

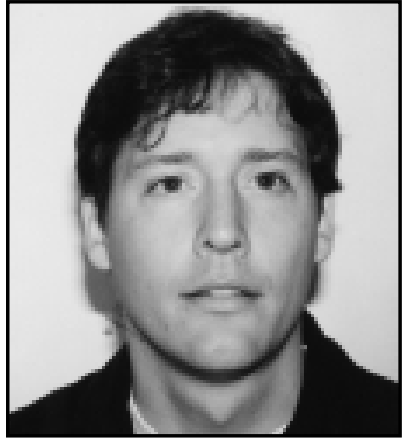

Van A. Lantz

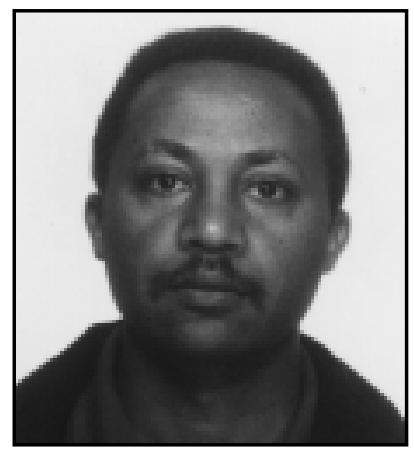

Yigezu A. Yigezu
A second concern with regard to the Fundy forest industry's future is the increasing pressure to maintain environmental quality in the forest. This concern has caused government officials and forest managers of both public and private forest land to implement policies directed toward both reducing harvesting scale and augmenting silvicultural practices in the province. ${ }^{5}$ One such policy initiative is the recent decision to protect approximately 150000 hectares of provincial forest land from harvesting operations (NBDNRE 2002). ${ }^{6}$

This policy is estimated to have reduced the annual timber supply throughout the province by approximately 160000 cubic meters (GP 2000). Continued environmental quality concerns may call for enhanced government and forest manager intervention to reduce the timber supply across more areas of New Brunswick. These actions, while creating many socio-economic

${ }^{5}$ Forest ownership in New Brunswick is divided between Crown (50\%), industrial freehold (30\%), and private woodlots (20\%). While public forest land has prescribed annual allowable cut (AAC) limits, private forest land management is increasingly being influenced by market demands (i.e., certification). ${ }^{6}$ There are a total of 10 areas that have been protected across New Brunswick. Three of these areas surround the perimeter of the FMF region. 
benefits for the region as a whole, often have significantly negative impacts on forest-dependent communities (Robinson and Freitag 1994).

Given the important role that the forest industry plays in the Fundy Model Forest region and the uncertainties that surround it, an in-depth understanding is needed of the underlying characteristics of this production sector, and its linkages with the rest of the economy. By understanding the socio-economic impact of market and policy changes in the forest industry, policy makers will be better prepared to help mitigate negative outcomes on the overall economy. In an effort to address the above issues, this paper will investigate the economic impacts of changes in forest product prices and the timber supply on a forest-dependent community in the region.

The case study region investigated in this paper is the community of Petitcodiac, located in the Fundy Model Forest, in southern New Brunswick. ${ }^{7}$

This community is chosen because it represents a midrange level of forest dependence in the region. The village itself covers a total area of about 17 square kilometres. For the purpose of this study, we have expanded the Petitcodiac boundary to include individuals in the surrounding area who would consider themselves Petitcodiac community members. This region is bounded by River Glade in the east, Anagance in the west, Elgin in the south, and New Canaan in the north.

The community of Petitcodiac is therefore defined as covering a total area of 1036 square kilometres out of which about $80 \%$ is forested. Ownership of the forest land is divided between Crown (15\%), private woodlot owners (65\%), and industrial freehold (20\%). The total population in this community is approximately 8000 .

According to Statistics Canada, the labour force participation rate in Petitcodiac is $53.1 \%$ of the total population (Statistics Canada 2002). The service sector is the principal employer (at 73\%) followed by manufacturing (at 14\%) and resource-based industries (at 13\%). There are a total of 515 businesses out of which 35 are directly forest-related (10 logging and 25 lumber/wood/pulp companies). Furthermore, according to village council members and key informants from the community, the forest industry contributes approximately $\$ 150$ million to the region's $\$ 500$ million GDP total, and employs approximately 600 of the 4770 full time equivalent workers. ${ }^{8}$ The lumber sector produces the lion's share of the forest industry's GDP, and employs about $80 \%$ of this industry's labour force. Additional information reveals that the 2002 average annual wage/salary for forest-related employees in the region is $\$ 23000$. This is approximately $\$ 3000$ above the aggregate industrial average in the region.

In order to investigate market and policy changes in the case study region, a two-sector (forest and composite), five-input (capital, labour, energy, land, timber) computable general equilibrium (CGE) model is specified. Although CGE models have been used in the past to study such changes, ours is uniquely specified and calibrated to the case-study region. Simulation results can be compared to other studies in order to provide some insight to the variation in regional impacts. Additionally, we follow Alavalapati et al. (1999b) in estimating the

\footnotetext{
${ }^{7}$ A map of the FMF can be found at NFA (2002).

${ }^{8}$ Personal communication with village council and business members from the Petitcodiac community, Petitcodiac, NB (2002).
}

market and policy impacts under both flexible and fixed wage scenarios. This provides some sense for how responsive the results are to a change in wage flexibility assumptions.

Calibrating the CGE model to the case study region requires estimation of a number of industry-level elasticity measures. In a recent study of the production structure in the Canadian forest industry, Lantz (1996) has shown that factor substitution elasticities, in particular, vary substantially across regions and sectors. Hence, we opt not to rely solely on national estimates produced in previous studies. Instead, we empirically estimate the required elasticities for the New Brunswick forest industry using a translog cost function approach. These estimates are used, together with other data gathered from statistical agencies and village council / business members, to calibrate the CGE model and run the market and policy simulations. The simulation results are compared to those that would have come about from using national elasticity estimates of Singh and Nautiyal (1986). The two sets of results will allow us to analyze the potential bias in using national elasticity estimates.

The organization of this paper is as follows. In the next section, a review of the CGE forestry literature is conducted. The following section explains the methodology and data sources of the study. A fifth section presents the results of the analysis. Then, a sixth section concludes the study.

\section{CGE literature}

CGE models have been used extensively for policy analysis in many industries at both inter-country and intra-country levels (Dervis et al. 1982, Shoven and Whalley 1984, Dixon et al. 1992). Their foundation rests on four basic assumptions that include: (i) market clearing; (ii) Walras Law (all markets are connected); (iii) utility maximization by households; and (iv) profit maximization by firms (Perman et al 1996).

One of the basic features of CGE models is that they are built on the recognition of the fundamental economic problem of resource constraints. Hence, they capture an important form of the intersectoral linkages in terms of their competition for the limited available resources. Unlike the I-O models, CGE models endogenously determine market equilibria for variables within the model. Additionally, CGE models provide a flexible framework where model assumptions can be modified to reflect the desired scenario. For instance, the relationship between inputs can be assumed as either one of no substitution or perfect substitution. Such modification possibilities provide the policy analyst a high degree of flexibility in specifying models that best fit the economy under investigation (Dervis et al. 1982).

CGE models are not, however, with out their own issues. Shoven and Whalley (1992) note that within the CGE framework: (i) little consensus exists regarding the magnitude of elasticities and other key parameters used in model specifications; (ii) large amounts of data are required to specify the model; and (iii) results may be quite sensitive to the key assumptions underlying the model (such as capital mobility, and competition assumptions). Although several issues arise when employing CGE analysis, a general consensus among researchers supports the view that this procedure provides an adequate framework for appraising the socio-economic effects of policy changes (Dervis et al. 1982; Shoven and Whalley 1992). ${ }^{9}$

\footnotetext{
${ }^{9}$ See Partridge and Rickman (1998) for a recent synthesis of the state of regional CGE modeling.
} 
A number of CGE studies have been conducted to address forest-related issues in a developed country context. Three recent studies in particular tend to focus on either forest product price or timber supply shocks (or both). ${ }^{10}$

Daniels et al. (1991), for instance, apply the CGE modeling technique to study the distributive effects of forest product price changes in the state of Montana. In this study, the authors evaluate the USDA Forest Service ability to maintain employment and income stability within forest-dependant communities. Specifying a two output (wood and composite) and three input (capital, labour, and timber) economy, the authors consider an $18 \%$ decrease in the price of wood products brought about from a decrease in final demand. They find that the demand for capital, labour and timber decreases in this sector. The released capital and labour shifts to the composite sector and, with the help of falling capital/labour/stumpage prices, cause an increase in output for this sector. Overall, the economy contracts from this price shock as the value of the composite sector expansion is less than the wood products contraction. Additionally, they find that the economy is increasingly responsive to a given lumber price shock when more elastic stumpage supplies and more constraints are assumed on factors of production.

If the state government of Montana were to maintain a given timber supply level in the case where wood product prices decreased by $18 \%$, a further adjustment in stumpage prices would occur in addition to that mentioned previously. This would partially mitigate the full market impact of the negative price shock in the forest sector and reduce the flow of factors into other sectors of the economy.

In another study, Binkley et al. (1994) investigate the economic impact of a reduction in harvest levels in British Columbia. They specify a nine output (with five representing the forest industry) and four input (labour, intermediate goods, capital, and forest land) economy. Simulating a 10\% decrease in the annual allowable cut (AAC), the authors find that overall employment and real GDP is reduced. The results are highly dependent on the assumption of fixed wages, capital, land, and timber supply. Allowing more flexibility in wages tends to reduce the negative impact on employment and output in the region.

A more recent CGE study conducted by Alavalapati et al. (1999b) considers changes in both forest product prices and the AAC. This 1999 article is most relevant to our study. Therefore, a detailed examination of the results is made. Specifically, Alavalapati et al. (1999b) calibrate a two-sector (forest products and composite) four-input (capital, labour, timber, land) CGE model economy to the Foothills Model Forest region in Alberta. Simulations conducted in the study (for both flexible and rigid wage scenarios) include: (i) a $6 \%$ reduction in the AAC; and (ii) a $10 \%$ reduction in the price of pulp. The AAC reduction, in the flexible wage scenario, causes a $1.2 \%$ decrease in the demand for labour (14 jobs), and a $2.47 \%$ decrease in the demand for capital ( $\$ 6.94$ million) in the forest sector. These reductions cause a $2.4 \%$ decrease in wages ( $\$ 2.54$ million), a $0.19 \%$ decrease in the price of capital (numeraire), and a $2.61 \%$ increase in stumpage cost (\$3.07 million) in this sector.

\footnotetext{
${ }^{10}$ Other studies have tended to focus on such forest-related issues as export policies (Alavalapati et al. 1998), stumpage policies (Alavalapati et al. 1997), climate change (Rose et al. 2000), tax policies (Boyd and Daniels 1985), livestock grazing (Waters et al. 1997), and technological change (Alavalapati et al. 1999a)
}

Overall, the forest sector experiences a $3.03 \%$ decrease in output ( $\$ 15.27$ million). The released inputs flow into the composite sector where there is a labour, capital, and output expansion experienced of $0.21 \%$ (10 jobs), 0.92\% (\$6.04 million), and $0.55 \%$ (\$11.10 million), respectively. This expansion, however, is out-weighted by the contraction in the forest sector such that aggregate capital, labour, and GDP decrease from this shock.

When considering a $10 \%$ pulp price decrease (emanating from increased supply from other countries), Alavalapati et al. (1999b) find that, under a flexible wage scenario, there is an $8.36 \%$ decrease in labour demand, and a $17 \%$ decrease in capital demand in the forest sector. These variable reductions cause a $16.72 \%$ decrease in wages, a $1.3 \%$ decrease in the price of capital, and a $24.75 \%$ decrease in stumpage costs. Overall, the forest sector experiences an $11.22 \%$ decrease in output. As in the case of the AAC shock described above, the released inputs flow into the composite sector where, in this case, there is a labour, capital, and output expansion of $1.44 \%, 6.36 \%$, and $3.76 \%$, respectively. Overall, however, aggregate capital, labour, and GDP decrease from this shock. In both simulations, the authors also report fixed-wage scenarios (brought about through unionized labour contracts). In general, the economic impacts tend to be similar, but larger, compared with the flexible case.

\section{Methodology}

The CGE model specified in this study is similar to that of Alavalapati et al. (1999b), Daniels et al. (1991), and Calves and Jones (1985). In these models, a two output (forest and composite) and four production factor (labour, capital, land, timber) economy is assumed. The regions under investigation are assumed to exhibit small open economies with constant returns to scale production technologies, perfect competition, and fixed commodity prices. ${ }^{11}$

Additionally, wages may be fixed or flexible, depending on the timing of economic shocks. ${ }^{12}$

Alavalapati et al. (1999b) make further assumptions that: (i) land and timber are in fixed supply; (ii) capital is the only mobile factor between sectors; and (iii) household income originates from wage income alone. The model developed in the current study, and described in more detail in Appendix 1, differs from these earlier models in its treatment of a number of important factors. Specifically, based on an interview with village council and business members of the Petitcodiac community, we assume that: (i) there are five factors of production (labour, capital, energy, land, timber); (ii) labour, capital, land, and timber supplies are responsive to their respective input price; ${ }^{13}$ (iii) labour, capital, and energy inputs are mobile between sectors and in/out of the region; ${ }^{14}$ and (iv) households receive income

\footnotetext{
${ }^{11}$ Fixed commodity prices result from the assumption that the agents in the economy are price takers (Alavalapati et al. 1999b).

${ }^{12}$ Wages may be rigid in the short run since some forestry and composite sector workers are unionized, and thus have fixed salaries.

${ }^{13}$ Land and timber supplies are expected to be responsive to input prices in regions where there is excess land capacity and a significant amount of forest land privately owned, respectively. Both of these circumstances exist in the case study region. We also assume that land and forest land released from composite and forestry production is not available for use in other sector (Alavalapati et al. 1997, 1999b).

${ }^{14}$ These assumptions result from community members' indications that these inputs do indeed move freely between sectors in the region (even in the immediate short run).
} 
from wage, capital/land rent, and stumpage revenues. Consequently, divergent simulation results are expected for the current New Brunswick study and those of Alavalapati et al.'s (1999b) Alberta study.

There are two major categories of data required for our CGE model analysis. These include production structure data and community-specific data. Since there does not exist sufficient publication of these data categories for our purposes, we use a hybrid approach by combining synthetic (non-survey) and survey techniques for the production structure and communityspecific data, respectively. ${ }^{15}$

More specifically, for the production structure data, we require estimates for price and factor substitution elasticities in the forest and composite sectors. We derive these elasticity estimates for the forest sector using a translog cost function regression similar to that employed by Kant and Nautiyal (1997). This functional form is the most widely used and accepted specification in the literature for estimating industrial cost structures (Martinello 1985). Data for the regression is largely collected from Statistics Canada (1965-95) and ESTAT (2002). Appendix 2 provides the details on the translog cost function technique and the data sources for this sector. Data for estimating the composite sector production structure, on the other hand, is not available in New Brunswick (or for Canada as a whole). As such, we compile the required elasticity estimates from those produced in the United States by Klein (1974), Fishelson (1979) Paraskevopoulos (1979) and Thompson (1997). ${ }^{16}$

As mentioned previously, the use of data estimates from other contexts may introduce bias in the results. This issue is addressed in our analysis of the forest sector by presenting simulation results based on both our New Brunswick elasticity estimates and national estimates provided by Singh and Nautiyal (1986). ${ }^{17}$ The composite sector elasticities, however, could not be estimated at the New Brunswick level as a result of data limitations. Thus, a bias may remain in the simulations presented below.

The second category of data required for CGE analysis is community-specific and thus require the use of survey techniques. Most of the data for the community of Petitcodiac is collected from a group interview with village council/business members from the community. Such information as: (i) the value of total output from the forest and the composite sectors; (ii) the total/share of employment for the sectors in the community; (iii) the average annual wage in each sector and the value of total timber used as input in the forest sector; (iv) the total capital in each sector; (v) the amount of energy consumed in the two sectors; and (vi) the price per kWh of energy has been estimated by the informants. ${ }^{18}$

This information was organized into a social accounting matrix and then used in the calibration of the CGE model parameters.

\footnotetext{
${ }^{15}$ See Patriquin et al. (2002) for a full description of hybrid approaches to data estimation.

${ }^{16}$ All input price and substitution elasticity estimates used in this study are available from the authors upon request.

${ }^{17}$ It should be noted here that a small bias may still exist with the provincial forest sector elasticity estimates since they are based on a larger region than the community of interest.

${ }^{18}$ The questionnaire given to the participants is available from the authors upon request.
}

\section{Results}

The CGE simulation results for marginal reductions in the lumber price and the timber supply are presented in Tables 1 and 2 , respectively. When the price of lumber decreases by $1 \%$ in the flexible wage scenario (Column 3 in Table 1), forest sector output decreases by $0.706 \%$ ( $\$ 1.059$ million). This causes the producer's demand for labour, capital, and timber to decrease by $0.982 \%$ (six jobs), $2.083 \%$ ( $\$ 0.313$ million), and $0.479 \%$ $\left(43,411.770 \mathrm{~m}^{3}\right)$, respectively. Energy demand, on the other hand, increases by $0.218 \%$ ( $\$ 0.016$ million) as firms make cost-efficient factor substitutions. These changes cause input suppliers to accept a $1.964 \%$ lower wage, a $0.042 \%$ lower rental rate of capital, and a $0.959 \%$ lower stumpage price.

The drop in the wage rate and the rental rate of capital in the lumber price simulation causes labour and capital to flow out of the forest sector and into other sectors of the economy where they receive higher returns. As a result, the composite sector experiences an increase in output of $0.088 \%$ ( $\$ 0.308$ million), in labour of $0.049 \%$ (two jobs), in capital of $0.156 \%$ (\$0.273 million), and in energy of $0.718 \%$ ( 0.251 million). Land demand decreases by $0.042 \%$ ( $6.527 \mathrm{ha}$ ) as firms make costefficient factor substitutions. These changes cause wages to increase by $0.098 \%$, and the rental rate of land to decrease by $0.085 \%$. Overall, the Petitcodiac community experiences a significant reduction in total output, labour, and capital in the region. This causes household income to be reduced by $0.778 \%$ (\$1.12 million).

Under the fixed-wage scenario (Column 4 in Table 1), the marginal lumber price reduction generally causes a similar, but greater, impact on most model variables relative to the flexible wage scenario. More specifically, the $1 \%$ reduction in the lumber price causes a relatively larger decrease in forest sector output (at 1.794\%), labour (at 1.063\%), and capital (at 2.428\%), and a relatively larger increase in composite sector output (at $0.031 \%$ ), labour (at $0.057 \%$ ), and capital (at $0.182 \%$ ). The only variables that react in a different manner are energy and household savings. In the case of fixed wages, energy in the forest sector is reduced by $0.189 \%$ (leading to a smaller overall increase in total energy in the economy). This reduction results from the combined effects of: (i) the complementary relationship that energy has with labour (embodied in the elasticity estimates employed); and (ii) the relatively large reduction in labour that results from the fixed wage assumption. The household income variable is reduced by a smaller amount (at $0.646 \%$ ) compared to the flexible-wage scenario due to the obvious support that non-declining wages provide to employment income.

When the timber supply is reduced by $1 \%$ in the flexible wage scenario (Column 3 in Table 2), forest sector output, labour, capital, and energy decrease by $8.863 \%, 0.590 \%, 0.864 \%$, and $0.836 \%$, respectively. These reductions cause downward pressure on forest sector wages by $1.180 \%$ and rental rates on capital by $0.017 \%$. Stumpage rates, on the other hand, increase by $0.320 \%$ as producers bid up the price of the declining input.

The wage rate and rental rate of capital reduction in the timber supply simulation again cause labour and capital to flow out of the forest sector and into other sectors of the economy. In this case, the composite sector experiences an increase in output, labour, capital, and energy of $0.037 \%, 0.020 \%, 0.065 \%$, and $0.409 \%$, respectively. Land demand decreases by $0.018 \%$ as firms make cost-efficient factor substitutions. These changes cause the wage rate to increase by $0.041 \%$, and the rental rate 
Table 1. Economic impact of a $1 \%$ decrease in the price of lumber for the Petitcodiac community using New Brunswick input substitution elasticity estimates ${ }^{\mathbf{a}}$

\begin{tabular}{|c|c|c|c|}
\hline \multirow[b]{2}{*}{ Variables } & \multirow[b]{2}{*}{ Base value $(2001)^{b}$} & \multicolumn{2}{|c|}{ Timber supply impact (in \% change) } \\
\hline & & Flexible wage scenario & Fixed wage scenario \\
\hline Output in forest sector $\left(\mathrm{X}_{\mathrm{F}}\right)$ & $\$ 150.0$ million & -0.706 & -1.063 \\
\hline Output in composite sector $\left(\mathrm{X}_{\mathrm{C}}\right)$ & $\$ 350.0$ million & 0.088 & 0.103 \\
\hline Labour in forest sector $\left(\mathrm{L}_{\mathrm{F}}\right)$ & 600 & -0.982 & -1.794 \\
\hline Labour in comp. sector $\left(\mathrm{L}_{\mathrm{C}}\right)$ & 4170 & 0.049 & 0.057 \\
\hline Total labour in economy (L) & 4770 & -0.162 & -0.321 \\
\hline Capital in forest sector $\left(\mathrm{K}_{\mathrm{F}}\right)$ & $\$ 15.0$ million & -2.083 & -2.428 \\
\hline Capital in comp. sector $\left(\mathrm{K}_{\mathrm{C}}\right)$ & $\$ 175.0$ million & 0.156 & 0.182 \\
\hline Total capital in economy $(\mathrm{K})$ & $\$ 190.0$ million & -0.021 & -0.024 \\
\hline Energy in forest sector $\left(\mathrm{E}_{\mathrm{F}}\right)$ & $\$ 7.5$ million & 0.218 & -0.189 \\
\hline Energy in comp. sector $\left(\mathrm{E}_{\mathrm{C}}\right)$ & $\$ 35.0$ million & 0.718 & 0.140 \\
\hline Total energy in economy (E) & $\$ 42.5$ million & 0.630 & 0.082 \\
\hline Timber in forest sector (M) & 9.063 mill. $\mathrm{m}^{3}$ & -0.479 & -0.743 \\
\hline Land in comp. sector (D) & 15540 ha & -0.042 & -0.049 \\
\hline Wage rate in forest sector $\left(\mathrm{W}_{\mathrm{F}}\right)$ & - & -1.964 & 0.000 \\
\hline Wage rate in comp. sector $\left(\mathrm{W}_{\mathrm{C}}\right)$ & - & 0.098 & 0.114 \\
\hline Rental rate of capital (R) & - & -0.042 & -0.049 \\
\hline Stumpage rate of timber $/ \mathrm{m}^{3}(\mathrm{~S})$ & - & -0.959 & -1.485 \\
\hline Rental rate of land/ha $(\mathrm{V})$ & - & -0.085 & -0.099 \\
\hline Income of household (Y) & $\$ 142.4$ million & -0.788 & -0.646 \\
\hline
\end{tabular}

${ }^{a}$ New Brunswick input substitution elasticity estimates are calculated from the translog cost function estimation described in Appendix 2.

b Entries with "-" indicate that the variable's base value is not required for the simulation.

Table 2. Economic impact of a $1 \%$ decrease in the timber supply for the Petitcodiac community using New Brunswick input substitution elasticity estimates $^{\mathbf{a}}$

\begin{tabular}{|c|c|c|c|}
\hline \multirow[b]{2}{*}{ Variables } & \multirow[b]{2}{*}{ Base value $(2001)^{b}$} & \multicolumn{2}{|c|}{ Price impact (in \% change) } \\
\hline & & Flexible wage scenario & Fixed wage scenario \\
\hline Output in forest sector $\left(X_{F}\right)$ & $\$ 150.0$ million & -0.863 & -0.930 \\
\hline Output in composite sector $\left(\mathrm{X}_{\mathrm{C}}\right)$ & $\$ 350.0$ million & 0.037 & 0.039 \\
\hline Labour in forest sector $\left(L_{F}\right)$ & 600 & -0.590 & -0.931 \\
\hline Labour in comp. sector $\left(\mathrm{L}_{\mathrm{C}}\right)$ & 4170 & 0.020 & 0.022 \\
\hline Total labour in economy (L) & 4770 & -0.104 & -0.173 \\
\hline Capital in forest sector $\left(\mathrm{K}_{\mathrm{F}}\right)$ & $\$ 15.0$ million & -0.864 & -0.925 \\
\hline Capital in comp. sector $\left(\mathrm{K}_{\mathrm{C}}\right)$ & $\$ 175.0$ million & 0.065 & 0.069 \\
\hline Total capital in economy $(\mathrm{K})$ & $\$ 190.0$ million & -0.009 & -0.009 \\
\hline Energy in forest sector $\left(\mathrm{E}_{\mathrm{F}}\right)$ & $\$ 7.5$ million & -0.831 & -0.929 \\
\hline Energy in comp. sector $\left(\mathrm{E}_{C}\right)$ & $\$ 35.0$ million & 0.409 & 0.053 \\
\hline Total energy in economy $(\mathrm{E})$ & $\$ 42.5$ million & 0.190 & -0.120 \\
\hline Timber in forest sector (M) & 9.063 mill. $\mathrm{m}^{3}$ & -1.000 & -1.000 \\
\hline Land in comp. sector (D) & $15540 \mathrm{ha}$ & -0.018 & -0.019 \\
\hline Wage rate in forest sector $\left(\mathrm{W}_{\mathrm{F}}\right)$ & - & -1.180 & 0.000 \\
\hline Wage rate in comp. sector $\left(\mathrm{W}_{C}\right)$ & - & 0.041 & 0.044 \\
\hline Rental rate of capital (R) & - & -0.017 & -0.019 \\
\hline Stumpage rate of timber $/ \mathrm{m}^{3}(\mathrm{~S})$ & _- & 0.320 & 0.003 \\
\hline Rental rate of land/ha (V) & - & -0.035 & -0.038 \\
\hline Income of household (Y) & $\$ 142.4$ million & -0.445 & -0.310 \\
\hline
\end{tabular}

${ }^{a}$ New Brunswick input substitution elasticity estimates are calculated from the translog cost function estimation described in Appendix 2.

b Entries with "-"indicate that the variable's base value is not required for the simulation.

of land to decrease by $0.035 \%$. Overall, the Petitcodiac community again experiences a significant reduction in total output, labour, and capital in the region. In this case, household income is reduced by $0.445 \%$.

The marginal timber supply reduction in the fixed-wage scenario (Column 4 in Table 2) once again causes a similar, but greater, impact on most model variables relative to the flexible wage scenario. The exceptions in this case include energy, household income, and the stumpage rate. The first two variables react differently for reasons explained earlier. The stumpage rate variable, however, increases by a smaller amount in the fixed-wage scenario as a result of the Euler's theorem assumption. Specifically, since factor payments exhaust total revenue in each sector and commodity prices/wages are assumed fixed, stumpage prices are required to increase only marginally to offset the relatively small increase in the rental rate of capital.

In order to provide a sense of the potential data bias inherent in CGE simulations, Tables 3 and 4 present the comparative lumber price and timber supply simulation results derived from the use of national elasticity estimates. Findings indicate that, while the timber supply simulations in Table 4 produce economic impacts that are quite close to those produced in the original simulations (Table 2), the lumber price simulations in Table 3 generally produce much lower impacts than those in the original simulations (Table 1). This indicates that a significant downward bias in lumber price impacts results when national elasticity estimates are used instead of provincial estimates. 
Table 3. Economic impacts of a $1 \%$ decrease in the price of lumber for the Petitcodiac community using national substitution elasticities (for comparative purposes only) ${ }^{\mathrm{a}}$

\begin{tabular}{|c|c|c|c|}
\hline \multirow[b]{2}{*}{ Variables } & \multirow[b]{2}{*}{ Base value $(2001)^{b}$} & \multicolumn{2}{|c|}{ Timber supply impact (in \% change) } \\
\hline & & Flexible wage scenario & Fixed wage scenario \\
\hline Output in forest sector $\left(\mathrm{X}_{\mathrm{F}}\right)$ & $\$ 150.0$ million & -0.530 & -0.668 \\
\hline Output in composite sector $\left(\mathrm{X}_{\mathrm{C}}\right)$ & $\$ 350.0$ million & 0.013 & 0.002 \\
\hline Labour in forest sector $\left(\mathrm{L}_{\mathrm{F}}\right)$ & 600 & -0.340 & -0.909 \\
\hline Labour in comp. sector $\left(\mathrm{L}_{\mathrm{C}}\right)$ & 4170 & 0.001 & 0.001 \\
\hline Total labour in economy (L) & 4770 & -0.068 & -0.186 \\
\hline Capital in forest sector $\left(\mathrm{K}_{\mathrm{F}}\right)$ & $\$ 15.0$ million & -0.300 & -0.048 \\
\hline Capital in comp. sector $\left(\mathrm{K}_{\mathrm{C}}\right)$ & $\$ 175.0$ million & 0.022 & 0.004 \\
\hline Total capital in economy $(\mathrm{K})$ & $\$ 190.0$ million & -0.003 & -0.001 \\
\hline Energy in forest sector $\left(\mathrm{E}_{\mathrm{F}}\right)$ & $\$ 7.5$ million & -1.061 & -0.648 \\
\hline Energy in comp. sector $\left(\mathrm{E}_{\mathrm{C}}\right)$ & $\$ 35.0$ million & -0.901 & 0.002 \\
\hline Total energy in economy $(\mathrm{E})$ & $\$ 42.5$ million & -0.929 & -0.113 \\
\hline Timber in forest sector (M) & 9.063 mill. $\mathrm{m}^{3}$ & -0.655 & -0.746 \\
\hline Land in comp. sector (D) & 15540 ha & 0.013 & 0.002 \\
\hline Wage rate in forest sector $\left(\mathrm{W}_{\mathrm{F}}\right)$ & - & -0.679 & 0.000 \\
\hline Wage rate in comp. sector $\left(\mathrm{W}_{\mathrm{C}}\right)$ & - & 0.003 & 0.001 \\
\hline Rental rate of capital (R) & - & -0.007 & -0.001 \\
\hline Stumpage rate of timber $/ \mathrm{m}^{3}(\mathrm{~S})$ & - & -1.309 & -1.492 \\
\hline Rental rate of land/ha (V) & - & 0.026 & 0.004 \\
\hline Income of household (Y) & $\$ 142.4$ million & -0.407 & -0.407 \\
\hline
\end{tabular}

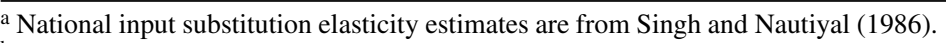

b Entries with "-" indicate that the variable's base value is not required for the simulation.

Table 4. Economic impact analysis of a $1 \%$ decrease in the timber supply for the Petitcodiac community using national substitution elasticity estimates (for comparative purposes only) ${ }^{\mathrm{a}}$

\begin{tabular}{lcrr}
\hline & & \multicolumn{2}{c}{ Price impact (in \% change) } \\
\cline { 2 - 4 } Variables & Base value (2001) & Fixed wage scenario \\
\hline Output in forest sector $\left(\mathrm{X}_{\mathrm{F}}\right)$ & $\$ 150.0$ million & -0.871 & -0.931 \\
Output in composite sector $\left(\mathrm{X}_{\mathrm{C}}\right)$ & $\$ 350.0$ million & 0.056 & 0.039 \\
Labour in forest sector $\left(\mathrm{L}_{\mathrm{F}}\right)$ & 600 & -0.386 & -0.936 \\
Labour in comp. sector $\left(\mathrm{L}_{\mathrm{C}}\right)$ & 4170 & -0.006 & 0.004 \\
Total labour in economy $(\mathrm{L})$ & 4770 & -1.311 & -0.188 \\
Capital in forest sector $\left(\mathrm{K}_{\mathrm{F}}\right)$ & $\$ 15.0$ million & 0.096 & -0.928 \\
Capital in comp. sector $\left(\mathrm{K}_{\mathrm{C}}\right)$ & $\$ 175.0$ million & -0.015 & 0.068 \\
Total capital in economy $(\mathrm{K})$ & $\$ 190.0$ million & -1.497 & -0.011 \\
Energy in forest sector $\left(\mathrm{E}_{\mathrm{F}}\right)$ & $\$ 7.5$ million & -0.980 & -0.931 \\
Energy in comp. sector $\left(\mathrm{E}_{\mathrm{C}}\right)$ & $\$ 35.0$ million & -1.071 & 0.044 \\
Total energy in economy $(\mathrm{E})$ & $\$ 42.5$ million & -1.00 & -0.128 \\
Timber in forest sector $(\mathrm{M})$ & 9.063 mill. $\mathrm{m}^{3}$ & 0.057 & -1.00 \\
Land in comp. sector $(\mathrm{D})$ & 15540 ha & -0.773 & 0.040 \\
Wage rate in forest sector $\left(\mathrm{W}_{\mathrm{F}}\right)$ & - & 0.012 & 0.000 \\
Wage rate in comp. sector $\left(\mathrm{W}_{\mathrm{C}}\right)$ & - & -0.030 & 0.008 \\
Rental rate of capital $(\mathrm{R})$ & - & 0.212 & -0.021 \\
Stumpage rate of timber/m $(\mathrm{S})$ & - & 0.113 & 0.003 \\
Rental rate of land/ha $(\mathrm{V})$ & - & -0.339 & 0.080 \\
Income of household $(\mathrm{Y})$ & $\$ 142.4$ million & & -0.307 \\
\hline
\end{tabular}

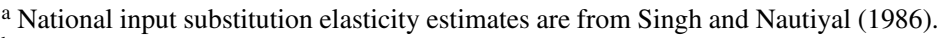

b Entries with "-_" indicate that the variable's base value is not required for the simulation.

The simulations presented in Tables 1 and 2 tend to follow closely in line with the results found in Alavalapati et al.'s (1999b) Alberta study, at least with regard to impact directions. When comparing a $1 \%$ reduction in the timber supply (or in their case AAC) simulations, however, the Alberta study produces much smaller percentage impacts than those in our New Brunswick study. ${ }^{19}$

While this may be an obvious result of regional variation in production structure, there may also be some bias created in the Alberta findings as a result of Alavalapati et al.'s (1999b)

${ }^{19}$ The Alberta study simulation results are converted to $1 \%$ reductions by assuming constant proportional changes as percentages are reduced (from $6 \%$ in the case of the AAC and $10 \%$ in the case of pulp prices) to $1 \%$. use of national elasticity estimates. However, since our correction for this previously mentioned bias did not significantly change the results in the New Brunswick timber supply simulation, only a re-calibration of the Alberta model would allow for this issue to be addressed.

The $1 \%$ reduction in forest product prices, on the other hand, tend to be much greater in Alavalapati et al.'s (1999b) Alberta study. This difference may be created, again, by the different production structures in each region. This factor is emphasized by the fact that different forest product prices were considered in each study (based on the most predominant forest sector in each region). Again, however, there may be an issue with the use of national elasticity estimates in the Alberta study. 


\section{Conclusions}

The forest sector is a significant contributor to the economic well being of the Petitcodiac community in New Brunswick. Any changes that affect the forest sector are likely to have substantial effects on the stability of the community. In an effort to examine potential future economic impacts of market and policy changes in the forest sector on the community of Petitcodiac, this paper has developed, calibrated, and run simulations on a CGE model for the region. Simulations have been conducted for a $1 \%$ reduction in the price of lumber and the timber supply. In general, we observe that both of these changes will have negative impacts (at least in the short run) on the economy and most factors of production. As production factors are released from this industry, they flow to other sectors, causing an increase in composite sector output. This expansion, however, is not large enough to offset the decline in the forest sector and therefore, aggregate output, labour, and capital is reduced in the region.

Although not modeled here, the above reductions in forest sector output may tend to increase passive-use values of the forest. This may induce the expansion of such sectors as eco-tourism and wildlife hunting, ultimately resulting in a stimulation of the local economy. Investigating such opportunities and building them into the analysis is the intention of the authors in a future study. Additionally, a full benefit-cost framework that incorporates the full range of socio-economic impacts is needed. Such a framework is essential in aiding decision-makers in their efforts to accommodate the increasing public demand for non-timber values (van Kooten 1993, Binkley et al. 1994).

\section{Acknowledgements}

Our appreciation is extended to the Fundy Model Forest for providing the financial assistance required to conduct this work. We would like to thank Dr. Mike Farnworth and Elizabeth Hamilton at the University of New Brunswick who provided feedback and helped gather the data required for the elasticity estimations in the study. Additionally, we would like to thank the village council and business community members in Petitcodiac who volunteered to participate in our interview. Lastly, we could like to thank the anonymous referees at the Forestry Chronicle for their helpful comments. The authors retain responsibility for all remaining errors.

\section{References}

Alavalapati, J.R., M.B. Percy and M.K. Luckert. 1997. A computable general equilibrium analysis of a stumpage price increase policy in British Columbia. Journal of Forest Economics 3(2): 143-169.

Alavalapati, J.R., W.L. Adamowicz and W.A. White. 1998. A comparison of economic impact assessment methods: the case of forestry development in Alberta. Can. J. For. Res., 28(5): 711-719.

Alavalapati, J.R., W.L. Adamowicz and W.A White. 1999a.Random variables in forest policy: a systematic sensitivity analysis using CGE models. Journal of Forest Economics 5(2): 321-335.

Alavalapati, J.R., W.A. White and M. Patriquin. 1999b. Economic impacts of changes in the forestry sector: a case study of the Foothills region in Alberta. For. Chron. 75(1): 121-127.

Banskota, K., W. Philips and T. Williamson. 1985. Factor substitution and economies of scale in the Alberta sawmill industry. Can. J. For. Res. 15(6): 1025-1030.

Berndt, E.R. and D.O. Wood. 1974. Technology, prices, and the derived demand for energy. University of British Columbia. Vancouver.

Binkley, C.S., M. Percy, W.A. Thompson and I.B. Vertinsky. 1994. A general equilibrium analysis of the economic impact of a reduction in harvest levels in British Columbia. For. Chron. 70(4): 449-454.
Blackorby, C. and R.R. Russell. 1989. Will the real elasticity of substitution please stand up? A comparison of the Allen/Uzawa and Morishma elasticities, American Economic Review 49(4): 882-888.

Boyd, R. and B.J. Daniels. 1985. Capital gains treatment of timber income: incidence and welfare implications. Land Economics 61(4): 354-362.

Calves, R.E. and R.W. Jones. 1985. World trade and payments: an introduction. Ed. 4. Little, Brown, Boston. 537 p.

Christensen, R. and W.H. Greene. 1976. Economies of scale in U.S. electric power generation. Journal of Political Economy 84(4): 655-675.

Daniels, S.E., W.F. Hyde and D.N. Wear. 1991. Distributive effects of Forest Service attempts at maintaining community stability. Forest Science 37(1): 245-260.

De Borger, B. and J. Buongiorno. 1985. Productivity growth in the paper and paperboard industries: a variable cost function approach. Can. J. of For. Res. 15: 1013-1020.

Dervis, K., J. De Melo and S. Robinson. 1982. General equilibrium models for development policy. Cambridge University Press, New York.

Dixon, P.B., B.R. Parmenter and A.A Powell. 1992. ORANI: notes and problems in applied general equilibrium economics. NorthHolland Publishing Company, Amsterdam.

ESTAT. 2002. Statistics Canada database. Available at http://estat.statcan.ca/

Fishelson, G. 1979. Elasticity of factor substitution in cross-section production functions. Review of Economics and Statistics 61(3): 432-436. GAMS. 2001. General algebraic modeling system. GAMS Development Corporation, DC.

GP. 2000. Socio-economic analysis for the protected areas strategy. Gardner Pinfold Consulting Economists Ltd. Prepared for the Department of Natural Resources and Energy, Fredericton, NB.

Hertel, T. W. 1988. General equilibrium incidence of natural resource subsidies: the three factor case. Journal of Environmental Economics and Management 15: 206-223.

Johanson, L. 1960. A Multi-sectoral Study of Economic Growth. NorthHolland, Amsterdam.

Kant, S. and J.C. Nautiyal. 1997. Production structure, factor substitution, technical change, and total factor productivity in the Canadian logging industry. Can. J. For. Res. 27: 701-710.

Klein, L. R. 1974. Issues in econometric studies of investment behavior. Journal of Economic Literature 12(1): 43-49.

Lantz, V. 1996. Elasticities of scale in the Canadian forest industry: a regional/sectoral approach (1965-95). Masters Thesis, Dalhousie University, Halifax.

MacGregor. 2001. Criteria and Indicators - Multiple Benefits to Society. Fundy Model Forest. Sussex, NB.

MacGregor, H. and D. MacFarlane. 2000. Revision of a socio-economic database for the Fundy Model Forest - five years later. Fundy Model Forest, Sussex, NB.

Martinello, F. 1985. Factor substitution, technical change, and returns to scale in Canadian forest industries. Can. J. For. Res. 15: 1116-1124.

Meil, J.K. and J. C. Nautiyal. 1988. An intra-regional economic analysis of production structure and factor demand in major Canadian softwood lumber producing regions. Can. J. For. Res. 18: 1036-1048.

NBDNRE. 2002. New Brunswick Protected Areas. New Brunswick Department of Natural Resources and Energy, Fredericton, NB.

NFA. 2002. Nova Forest Alliance Web site. Available at http://www.novaforestalliance.com/nfa/nfa_e/wel_e/fmf_mapse.htm NSFPMB. 2002. North Shore Forest Marketing Board. Available at: http://www. forestrysyndicate.com/en/

Paraskevopoulos, C. 1979. Alternative estimates of elasticity of substitution: an inter-metropolitan CES production function analysis of U.S. manufacturing industries, 1958-1972. Review of Economics and Statistics 61(3): 439-442. 
Partridge, M.D. and D.S. Rickman. 1998. Regional computable general equilibrium modeling: a survey and critical appraisal. International Regional Science Review 21(3): 205-248.

Patriquin, M.N., J.R. Alavalapati, A.M Wellstead and W.A. White. 2002. A comparison of impact measures from hybrid and synthetic techniques: A case study of the Foothills Model Forest. Annals of Regional Science 36: 265-278.

Perman, R., Y. Ma and J. McGilvray. 1996. Natural Resource and Environmental Economics. Addison Wesley Longman, New York. Robinson, M. and J. Freitag. 1994. The economic impact to local communities of eliminating the Wallowa-Whitman National Forest timber program. Robinson and Associates, Moscow. 57 p.

Rose A, Y. Cao and G. Oladosu. 2000. Simulating the economic impacts of climate change in the Mid-Atlantic Region. Climate research 14: 175-183.

Shoven, J.B. and J. Whalley. 1984. Applied general-equilibrium models of taxation and international trade: an introduction and survey. Journal of Economic Literature 22(3): 1007-1051.

Singh, B. and J. Nautiyal. 1986. A comparison of observed and longrun productivity of and demand for inputs in the Canadian lumber industry. Can. J. For. Res. 16: 443-455.

Sohngen, R. Mendelsohn, R. Sedjo and K. Lyon. 1997. An analysis of global timber markets. Resources for the Future. DC. 97-37. Statistics Canada. 1965-95. Canadian Forestry Statistics, Statistics Canada, Ottawa.

Statistics Canada. 2002. Community Profiles. Available at: http://ceps.statcan.ca/english/profil/

Details/ details1.cfm?ID $=2739 \&$ PSGC $=13 \&$ SGC $=1307029 \&$ DataType $=1 \&$ LANG $=E \&$ Province $=13 \&$ PlaceName $=$ Peti $\& C M A=0 \& C S D$

NAME $=$ Petitcodiac $\& A=\&$ TypeNameE $=$ Village

Thompson H. 1997. Substitution elasticities with many inputs. Applied Mathematical Literature 10(3): 123-127.

van Kooten, G.C. 1993. Land resource economics and sustainable development: economic policies and the common good. Vancouver: UBC Press. $450 \mathrm{p}$.

Waters, E.C., D.W. Holland and R.W. Haynes. 1997. The economic impact of public resource supply constraints in Northeast Oregon. USDA, Forest Service, Pacific Northwest Research Station. Technical Report PNW-GTR-398.

\section{Appendix 1: The CGE model structure}

\section{A. Commodity Supply}

Assuming a competitive economy with constant returns to scale technologies, we can derive identities that describe the relationship between the total supply of a commodity and its factor shares. Taking the changes in these relationships results in the following commodity supply equations: ${ }^{20}$

$$
\begin{aligned}
& X_{F}{ }^{\prime}=\theta_{L F} L_{F}^{\prime}+\theta_{K F} K_{F}^{\prime}+\theta_{E F} E_{F}^{\prime}+\theta_{M F} M_{F}{ }_{F} \\
& X_{C}{ }^{\prime}=\theta_{L C} L_{C}{ }_{C}+\theta_{K C} K_{C}{ }_{C}+\theta_{E C} E_{C}{ }^{\prime}+\theta_{D C} D^{\prime}{ }_{C}
\end{aligned}
$$

where for $i=[$ forest $(\mathrm{F})$, composite $(\mathrm{C})]$ and $\mathrm{k}=[\operatorname{labour}(\mathrm{L})$, capital(K), energy $(\mathrm{E})$, timber(M), land(D)], $X_{i}$ is the quantity of domestic product supplied by the $i^{\text {th }}$ sector, and $\theta_{k i}$ is the share of input $k$ in the cost of producing output $i$.

\section{B. Factor Demand}

The competitive market and constant returns to scale assumptions allow us to derive identities that relate factor input demands to factor prices and output. Taking the changes

\footnotetext{
${ }^{20}$ Apostrophes on variables indicate proportional changes (i.e., $F^{\prime}=d X / X$ ) This proportional change technique is referred to as the Johanson (1960) approach, and is employed by most of the CGE references cited throughout this study.
}

in these relationships results in the following set of factor demand equations:

$$
\begin{aligned}
L_{F}^{\prime}= & \theta_{L F} \sigma_{L L}^{F} W_{F}^{\prime}+\theta_{K F} \sigma_{L K}^{F} R^{\prime}+\theta_{M F} \sigma_{L M}^{F} S^{\prime} \\
& +\theta_{E F} \sigma^{F}{ }_{L E}^{\prime}+X_{F}^{\prime},
\end{aligned}
$$

$$
\begin{aligned}
K_{F}^{\prime}= & \theta_{L F} \sigma^{F}{ }_{K L} W_{F}^{\prime}+\theta_{K F} \sigma_{K K}^{F} R^{\prime}+\theta_{M F} \sigma_{K M}^{F} S^{\prime} \\
& +\theta_{E F} \sigma^{F}{ }_{K E} G^{\prime}+X_{F},
\end{aligned}
$$

$$
\begin{aligned}
M_{F}^{\prime}= & \theta_{L F} \sigma_{M L}^{F} W_{F}^{\prime}+\theta_{K F} \sigma_{M K}^{F} R^{\prime}+\theta_{M F} \sigma_{M M}^{F} S^{\prime} \\
& +\theta_{E F} \sigma_{M E}^{F} G^{\prime}+X_{F},
\end{aligned}
$$

$$
\begin{aligned}
E_{F}^{\prime}= & \theta_{L F} \sigma_{E L}^{F} W_{F}^{\prime}+\theta_{K F} \sigma_{E K}^{F} R^{\prime}+\theta_{M F} \sigma_{E M}^{F} S^{\prime} \\
& +\theta_{E F} \sigma_{E E}^{F} G^{\prime}+X_{F},
\end{aligned}
$$

$$
\begin{aligned}
L_{C}^{\prime}= & \theta_{L C} \sigma^{C}{ }_{L L} W^{\prime}{ }_{C}+\theta_{K C} \sigma^{C}{ }_{L K} R^{\prime}+\theta_{D C} \sigma^{C}{ }_{L D} V^{\prime} \\
& +\theta_{E C} \sigma_{L E}^{C} G^{\prime}+X_{C},
\end{aligned}
$$

$$
\begin{aligned}
K_{C}{ }_{C}= & \theta_{L C} \sigma^{C}{ }_{K L} W^{\prime}{ }_{C}+\theta_{K C} \sigma^{C}{ }_{K K} R^{\prime}+\theta_{D C} \sigma^{C}{ }_{K D} V^{\prime} \\
& +\theta_{E C} \sigma_{K E}^{C}{ }^{\prime}+X_{C},
\end{aligned}
$$

$$
\begin{aligned}
D^{\prime}{ }_{C}= & \theta_{L C} \sigma^{C}{ }_{D L} W^{\prime}{ }_{C}+\theta_{K C} \sigma^{C}{ }_{D K} R^{\prime}+\theta_{D C} \sigma_{D D}^{C} V^{\prime} \\
& +\theta_{E C} \sigma_{D E}^{C} G^{\prime}+X_{C},
\end{aligned}
$$

$$
\begin{aligned}
E_{C}^{\prime}= & \theta_{L C} \sigma_{E L}^{C} W_{C}^{\prime}+\theta_{K C} \sigma_{E K}^{C} R^{\prime}+\theta_{D C} \sigma_{E D}^{C} V^{\prime} \\
& +\theta_{E C} \sigma_{E E}^{C} G^{\prime}+X_{C}{ }^{\prime}
\end{aligned}
$$

where $W_{i}$ is the wage rate in the $i^{\text {th }}$ sector, $R$ is the rental price of capital, $S$ is the stumpage price, $G$ is the price of electricity, $V$ is the rental price of land, $\sigma$ 's are the partial elasticities of substitution between factor inputs.

Restrictions on the cost share weighted elasticities of substitution permit one of the demand equations from each sector to be dropped and determined residually (Hertel 1988). Accordingly, the timber demand equation from the forest sector and the land demand equation from the composite sector have been dropped from the system.

\section{Factor Supply}

The households' and producers' respective utility and profitmaximizing conditions allow us to derive the factor supply functions. Additionally, we can specify equations that allow for the free mobility of inputs across production sectors. Based on our interview with community members in the case study region, we assume that: (i) labour, capital, timber, and land supplies are responsive to changes in their prices; (ii) energy is supplied in unlimited quantity; and (iii) labour, capital, and energy are freely mobile across production sectors and into/out of the region. Taking the changes in these relationships results in the following set of factor supply equations:
(11) $L_{F}^{\prime}=\eta_{F} W_{F}^{\prime}$
(12) $L_{C}^{\prime}=\eta_{C} W^{\prime}{ }_{C}$
(13) $K^{\prime}=\kappa_{R} R^{\prime}$
(14) $M_{F}^{\prime}=\lambda_{S} S^{\prime}$ 
(15) $D^{\prime}{ }_{C}=\mu_{V} V^{\prime}$

(16) $L^{\prime}=v_{L F} L_{F}^{\prime}+v_{L C} L_{C}^{\prime}$

(17) $K^{\prime}=\xi_{K F} K_{F}^{\prime}+\xi_{K C} K_{C}^{\prime}$

(18) $E^{\prime}=\pi_{E F} E_{F}^{\prime}+\pi_{E C^{E}}{ }_{C}$

where $\eta_{i}, \kappa_{R}, \lambda_{S}$, and $\mu_{V}$ are the supply elasticities of labour, capital, timber, and land in sector $i$, respectively, and $v_{L i}$, $\xi_{K}$, $\pi_{E i}$ are the shares of sector $i$ in total labour, capital, and energy, respectively.

\section{Profits}

The competitive market and constant returns to scale assumptions imply zero producer profits. This results because input factors are paid their opportunity costs and, as shown above, factor payments exhaust the total revenue in each industry (Euler's theorem). Taking the changes in these relationships results in the following zero profit conditions:

$$
\begin{aligned}
& P_{F}^{\prime}=\theta_{L F} W_{F}^{\prime}+\theta_{K F} R^{\prime}+\theta_{M F} S^{\prime}+\theta_{E F} E^{\prime} \\
& P_{C}^{\prime}=\theta_{L C} W_{C}^{\prime}+\theta_{K C} R^{\prime}+\theta_{D C} V^{\prime}+\theta_{E C} E^{\prime}
\end{aligned}
$$

where $P_{i}$ is the market price of the $i^{\text {th }}$ sector product.

\section{E. Household Income}

According to a household's utility maximization problem, we can derive an identity that relates total household income to the shares of income sources. Based on our interview with community members in the case study region, we assume that income is generated from labour, capital, timber, and land supply by households. Taking the change in the household income relationship results in the following equation:

$$
\begin{aligned}
(21) Y^{\prime}= & \zeta_{L F W F}\left(L_{F}^{\prime}+W^{\prime}{ }_{F}\right)+\zeta_{L C W C}\left(L_{C}{ }_{C}+W^{\prime}{ }_{C}\right) \\
& +\zeta_{K R}\left(K^{\prime}+R^{\prime}\right)+\zeta_{M S}\left(M^{\prime}+S^{\prime}\right)+\zeta_{D V}\left(D^{\prime}+V^{\prime}\right)
\end{aligned}
$$

where $Y$ represents household income, and $\zeta$ 's are the shares of income sources.

The above system encompasses 22 unknown variables in 19 equations. The aforementioned assumption of constant commodity and energy prices reduces the unknown variables to 19 . With these conditions, equilibrium can be established in the economic system and simulations can be performed by exogenously setting the policy variable(s) of interest. ${ }^{21}$

The GAMS 20.5 (2001) software package is used to perform the simulations.

\section{Appendix 2: Production structure of the saw and planning mill sector in New Brunswick}

Following the methodology employed by Kant and Nautiyal (1997), we characterize the production structure of the saw and planning mill sector in the region by specifying a translog

${ }^{21}$ When considering the fixed-wage scenario, we replace equation (11) with the restriction $\mathrm{W}_{\mathrm{F}}^{\prime}=0$. cost function. The resulting cost and cost share equations are as follows:

(22) $\ln C=\ln \sigma_{0}+\sigma_{Y} \ln Y+1 / 2 \sigma_{Y Y}[\ln Y]^{2}+\sigma_{Y K} \ln Y$

$\ln \left(P_{K} / P_{E}\right)+\sigma_{Y L} \ln Y \ln \left(P_{L} / P_{E}\right)+\sigma_{Y M} \ln Y \ln \left(P_{M} / P_{E}\right)$

$+\sigma_{K} \ln \left(P_{K} / P_{E}\right)+\sigma_{L} \ln \left(P_{L} / P_{E}\right)+\sigma_{M} \ln \left(P_{M} / P_{E}\right)$

$+1 / 2 \sigma_{K K}\left[\ln \left(P_{K} / P_{E}\right)\right]^{2}+\sigma_{K L} \ln \left(P_{K} / P_{E}\right) \ln \left(P_{L} / P_{E}\right)$

$+\sigma_{K M} \ln \left(P_{K} / P_{E}\right) \ln \left(P_{M} / P_{E}\right)+1 / 2 \sigma_{L L}\left[\ln \left(P_{L} / P_{E}\right)\right]^{2}$

$+\sigma_{L M} \ln \left(P_{L} / P_{E}\right) \ln \left(P_{M} / P_{E}\right)+1 / 2 \sigma_{M M}\left[\ln \left(P_{M} / P_{E}\right)\right]^{2}$

$+\sigma_{T} \ln T+\sigma_{T T}[\ln T]^{2}+\sigma_{T K} \ln T \ln \left(P_{K} / P_{E}\right)$

$+\sigma_{T L} \ln T \ln \left(P_{L} / P_{E}\right)+\sigma_{T M} \ln T \ln \left(P_{M} / P_{E}\right)$

$$
\begin{aligned}
S_{K}= & \sigma_{K}+\sigma_{Y K} \ln Y+\sigma_{K K} \ln \left(P_{K} / P_{E}\right)+\sigma_{K L} \ln \left(P_{L} / P_{E}\right) \\
& +\sigma_{K M} \ln \left(P_{M} / P_{E}\right)+\sigma_{T K} \ln T+\tau_{K}
\end{aligned}
$$

$$
\begin{aligned}
S_{L}= & \sigma_{L}+\sigma_{Y L} \ln Y+\sigma_{K L} \ln \left(P_{K} / P_{E}\right)+\sigma_{L L} \ln \left(P_{L} / P_{E}\right) \\
& +\sigma_{L M} \ln \left(P_{M} / P_{E}\right)+\sigma_{T L} \ln T+\tau_{L}
\end{aligned}
$$

$$
\begin{aligned}
S_{M}= & \sigma_{M}+\sigma_{Y M} \ln Y+\sigma_{K M} \ln \left(P_{K} / P_{E}\right)+\sigma_{L M} \\
& \ln \left(P_{L} / P_{E}\right)+\sigma_{M M} \ln \left(P_{M} / P_{E}\right)+\sigma_{t M} \ln T+\tau_{M}
\end{aligned}
$$

where $C$ is the cost function of producing output $Y, T$ is an indictor of technological progress, $P_{k}$ is the respective price of input $k, S_{i}$ represents the share of input $i$ 's cost in total costs of production, and $\sigma$ 's are parameters to be estimated.

The system of equations (22)-(25) is estimated as a multivariate regression system using the iterative Zellner estimation procedure (Berndt and Wood 1974). ${ }^{22}$

The likelihood ratio test is then used to determine whether or not the production structure is homothetic, homogeneous, and unit-elastic (Kant and Nautiyal, 1997). Findings indicate that the non-homothetic, non-homogenous and non-unitary elasticity of substitution production function associated with the above cost function best describes the production structure in the saw and planning mills in New Brunswick. Within this structure then, the input price elasticities of demand and the Morishma elasticities of substitution (MES) are calculated. ${ }^{23}$

As mentioned previously, the major forest sector in the Peticodiac community is lumber, representing over $80 \%$ of the forest production value. As such, we focus on this sector when collecting our translog cost function data. The main data sources used in the analysis are produced by Statistics Canada (1965-1995) and the ESTAT (2002) database. Annual data for volume of lumber produced in the saw and planning mills in New Brunswick (in $\mathrm{m}^{3}$ ) were obtained from the ESTAT database, Table No. 303-0009. The expenditures on energy, timber, and labour are estimated as the cost of fuel and electricity, materials and supplies, and wages and salaries (obtained from by Statistics Canada 1965-1995, Cat. No. 25-202).

\footnotetext{
${ }^{22}$ For the cost function to be well behaved, it has to be concave in the input prices, and its input demand functions should strictly be positive (Berndt and Wood 1974). These conditions were satisfied at all points in the sample.

${ }^{23}$ Although many studies have used the Allen elasticities of substitution in the past (Christensen and Greene 1976, Banskota et al. 1985, De Borger and Buongiorno 1985, Martinello 1985, Singh and Nautiyal 1986, Lantz 1996, Meil and Nautiyal 1988 and Kant and Nautiyal 1997 all employ Allen elasticities), Blackorby and Russell (1989) and Kant and Nautiyal (1997) argue that Morishma elasticities may better reflect the complex nature of the relationships.
} 
The price of labour is computed as a wage index and is estimated as the ratio of wages and salaries to the number of employees in the saw and planning mills. The price of timber is taken from ESTAT (2002), Table No. 330-0001 (1,2). This data, however, was not available for the period prior to 1981. Since the price index of timber and that of lumber for the period 1981-1995 exhibit similar trends over the years (verified by fitting an OLS trend to the individual time series), the trend in the price index lumber for the period prior to 1981 can be used to estimate timber prices.

Electric power is the major source of energy in the Saw and Planning mills. Hence, we have taken the price index of electricity for non-residential use in New Brunswick to represent the overall price index of energy. The price indices of electricity (for the period 1973-1995) have been taken from Statistics Canada (2001), Cat. No. 62-011 (and converted into the same base year). As there was no data for the years before 1973, we fitted a time trend of this variable for the period
1973-1995. Findings indicated a more or less linear trend. Consequently, we have used the average annual percentage growth in the price index of electricity throughout these years (which is about 15\%) to estimate the price index for the 1965-73 period.

Researchers have used a variety of techniques to calculate the cost and price of capital in a given production year. ${ }^{24} \mathrm{We}$ specify capital costs as the sum of repair and maintenance, depreciation, and nominal income foregone (product of nominal interest rate and the value of net fixed assets) expenditures. These data were obtained from Statistics Canada (1965-99), Cat. Nos. 61-207, 61-003, and 61-219. Capital prices are derived as the ratio of net profit $(=$ price of timber $\times$ volume of timber sold - total cost of production) and total capital expenditure from the sources listed above. Following Singh and Nautiyal (1986), the price of capital is smoothed by fitting an OLS time trend to the series.

${ }^{24}$ See Banskota et al. (1985) and Kant \& Nautiyal (1997) for examples of alternative specifications. 